FREITAS, ARJ; FREITAS, FCL; SOUZA, CM; DELAZARI, FT; BERGER, PG; BORGES, FJG; ZANUNCIO, JC. 2021. Biodegradable mulch controls weeds and increases water use efficiency in lettuce crops. Horticultura Brasileira 39: 330-334. DOI: http://dx.doi.org/10.1590/s0102-0536-20210314

\title{
Biodegradable mulch controls weeds and increases water use efficiency in lettuce crops
}

\author{
Agnaldo Roberto de J Freitas ${ }^{1} \mathbb{D}$; Francisco Claudio L de Freitas ${ }^{1 \mathbb{D}}$; Caetano Marciano de Souza ${ }^{1} \mathbb{D}$; Fabio

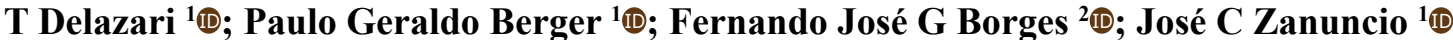

1'Universidade Federal de Viçosa (UFV), Viçosa-MG, Brasil; agnaldohu@gmail.com; francisco.freitas@ufv.br; cmsouzaufv@gmail.com; fabiodelazari@gmail.com; pgberger@ufv.br; zanuncio@ufv.br; ${ }^{2}$ Universidade Federal Rural do Rio de Janeiro (UFRRJ), Seropédica-RJ, Brasil; fjbgomes@yahoo.com.br

\begin{abstract}
Vegetable cultivation requires high water use and weed control. Soil cover using recycled paper, can be an alternative to polyethylene film to reduce weed incidence, soil temperature and increase water use efficiency beyond reduces costs and environmental pollutions. The objective of this study was to evaluate the use of biodegradable mulch in weed management and water use efficiency (WUE) in lettuce crop. The treatments were composed of brown recycled paper (RP), black polyethylene film (PF) and soil without cover with weed removal (WR) and without weed removal (WW). RP and PF were efficient to control weeds. The soil temperature with RP was 8.2 and $2.1^{\circ} \mathrm{C}$ lower than with PF and WR, respectively. The lettuce yield with RP was 14.5 and $28.3 \%$ higher than WR, and with PF, respectively. The water volume applied with RP was $26.5 \%$ lower, and WUE was $55.6 \%$ higher compared to WR. Soil cover with recycled paper controlled weeds, reduced soil temperature and water consumption and increased yield and water use efficiency in lettuce crop.
\end{abstract}

Keywords: Lactuca sativa, recycled paper, polyethylene film, thermal amplitude, applied water.

\section{RESUMO}

Mulch biodegradável controla plantas daninhas e aumenta a eficiência do uso de água na cultura da alface

O cultivo de hortaliças requer alto consumo de água e controle de plantas daninhas. A cobertura do solo com papel reciclado pode ser uma alternativa biodegradável ao filme de polietileno para reduzir a incidência de plantas daninhas, temperatura do solo e aumentar a eficiência do uso da água além de reduzir custos e poluição ambiental. O objetivo deste estudo foi avaliar o uso do mulch biodegradável no manejo de plantas daninhas e eficiência do uso da água (EUA) na cultura da alface. Os tratamentos foram papel reciclado marrom (RP), filme de polietileno preto (PF) e solo sem cobertura com remoção de plantas daninhas (WR) e sem remoção de plantas daninhas (WW). $\mathrm{O}$ RP e PF foram eficientes no controle das plantas daninhas. A temperatura do solo com RP foi 8,2 e $2,1^{\circ} \mathrm{C}$ menor que PF e WR, respectivamente. A produtividade da alface com RP foi 14,5 e 28,3\% superior ao WR e PF, respectivamente. $\mathrm{O}$ volume de água aplicado com RP foi $26,5 \%$ menor e EUA foi $55,6 \%$ maior em comparação a WR. A cobertura do solo com papel reciclado controlou a incidência de plantas daninhas, reduziu a temperatura do solo e o consumo de água e aumentou a produtividade e eficiência do uso da água na cultura da alface.

Palavras-chave: Lactuca sativa, papel reciclado, filme de polietileno, amplitude térmica, água aplicada.

Received on March 12, 2021; accepted July 27, 2021

L ettuce is the most consumed leafy vegetable in Brazil (Silva et al., 2017). This plant has a high transpiration rate and demands irrigation (Barbosa et al., 2015). Weeds can reduce lettuce crop productivity (Odero \& Wright, 2013) and are usually controlled by manual weeding, due to a lack of effective herbicides registered for this crop, and intensive soil rotation (Lati et al., 2015).

Alternative methods for weed control and water use efficiency may include soil cover with inorganic and organic materials (Kader et al., 2017a). The polyethylene film is the most used inorganic material to cover soil with high efficiency for weed control and reduced water use (Steinmetz et al., 2016). However, the black polyethylene film increases soil temperature $(\mathrm{Gu}$ et al., 2018), reduces plant crop and microorganism growth (Lamont, 2005; Schirmel et al., 2018). The polyethylene film has high degradation resistance, which does not allow it to be incorporated into the soil, with its removal and elimination after the cultivation, being necessary increased costs and leading to environmental contamination (Kyrikou, 2007; Steinmetz et al., 2016).

Organic materials such as plant residues (leaves, branches, crop residues, etc.) reduce weed incidence and soil temperature and increase soil moisture (Kader et al., 2017a). Paper is a biodegradable material used to cover soil with effective temperature reduction (Zhang et al., 2009; Haapala et al., 2014), weed control (Moreno et al., 2013; Haapala et al., 2015) and soil moisture maintenance over 
longer periods (Kader et al., 2017b), It reduces water consumption and increases its efficiency of use. Recycled paper consists of cellulosic and mineral calcium carbonate (Hubbe \& Gill, 2016), is biodegradable and do not need to be removed from the field, being possible its incorporation into the soil, reducing costs (Haapala et al., 2014). Moreover, its decomposition allows the release of calcium into the soil.

The objective was to evaluate the use of biodegradable mulch in weed management and water use efficiency in lettuce crop.

\section{MATERIAL AND METHODS}

The experiment was carried out in plastic greenhouse in the municipality of Viçosa, Minas Gerais, Brazil $\left(20^{\circ} 45^{\prime} 28^{\prime} \mathrm{S}, 42^{\circ} 50\right.$ ' $45^{\prime \prime} \mathrm{W}, 645 \mathrm{~m}$ altitude) in summer 2017. The maximum and minimum temperatures were 30.10 and $18.65^{\circ} \mathrm{C}$ with average $24.37^{\circ} \mathrm{C}$, and solar radiation $10.57 \mathrm{MJ} \mathrm{m}^{-2}$ day $^{-1}$ day $^{-1}$. The relative humidity of $81.42 \%$ was recorded in the Irriplus E5000 weather station.

The soil in the experimental area was classified as clayey, presenting average organic matter content of 1.8 $\mathrm{dag} / \mathrm{kg}$. The average bulk density was $1.25 \mathrm{~g} \mathrm{~cm}^{-3}$ and the moisture for the field capacity and wilting point were 0.36 and $0.20 \mathrm{~m}^{3} \mathrm{~m}^{-3}$, respectively.

The lettuce cv. Vera seeds were sown in 200 cell polyethylene trays with commercial Plantimax ${ }^{\circledR}$ substrate. Lettuce plants were transplanted 18 days after being sown.

The experimental design was completely randomized with four treatments and five replications. The treatments consisted of soil covered with brown recycled paper $\left(131 \mathrm{~g} \mathrm{~m}^{-2}\right)(\mathrm{RP})$ from Ponte Nova Papéis, Ponte NovaMG, BR with black polyethylene film $(22 \mu \mathrm{m})(\mathrm{PF})$ from Eletro Plastic, São Paulo-SP, BR, soil without cover with weed removal (WR) and soil without cover and without weed removal (WW). The dimensions of each experimental unit were $2.0 \times 1.0 \mathrm{~m}$ with the plants spaced at $0.25 \times 0.25 \mathrm{~m}$.

Beds $(10.0 \times 1.0 \mathrm{~m}$ with $0.2 \mathrm{~m}$ height) were made after soil preparation consisting of one plowing and harrowing. Planting fertilization with $50 \mathrm{~kg} \mathrm{ha}^{-1} \mathrm{~N}, 50 \mathrm{~kg} \mathrm{ha}^{-1} \mathrm{P}, 20 \mathrm{~kg} \mathrm{ha}^{-1}$ $\mathrm{K}$, was carried out with ammonium sulphate, simple superphosphate and potassium chloride, respectively, based on the soil analysis and recommendation (Ribeiro et al., 1999). Fertilization with $100 \mathrm{~kg} \mathrm{ha}^{-1} \mathrm{~N}, 0 \mathrm{~kg} \mathrm{ha}^{-1} \mathrm{P}, 40 \mathrm{~kg} \mathrm{ha}^{-1}$ $\mathrm{K}$, was carried out by fertigation at 10 and 20 days after transplanting (DAT) with ammonium sulfate and potassium chloride, respectively.

Dripping tapes with flow emitters of $1.60 \mathrm{~L} \mathrm{~h}^{-1}$, spaced $0.20 \mathrm{~cm}$ on the tape, were laid longitudinally on the beds spaced $50 \mathrm{~cm}$ apart. Each drip tape irrigated two lettuce rows. Irrigation was carried out according to the soil water tension obtained by the tensiometer reading per treatment in all repetitions, installed at a depth of $10 \mathrm{~cm}$, based on the water characteristic curve to maintain the soil field capacity.

Digital sensors, model DS18B20 (DFRobot, CN), with an accuracy of $\pm 0.5^{\circ} \mathrm{C}$, were installed $5 \mathrm{~cm}$ deep at the center of each experimental unit in all treatments and repetitions to monitor soil temperature during the crop cycle, every $15 \mathrm{~min}$ and stored in dataloggers constructed with a protoboard, Arduino Uno (DFRobot, CN).

The soil was covered with polyethylene film or recycled paper after fertilization and installation of the irrigation system. Circular holes of $3.0 \mathrm{~cm}$ diameter were opened in the polyethylene film and recycled paper to transplant the lettuce.

A $25 \mathrm{~mm}$ water blade was applied in all treatments after plant setting. Manual weeding was performed at 10 and 20 (DAT), in the treatment without cover with weed removal (WR).

Weed population density and dry matter were evaluated in a $0.5 \times 0.5 \mathrm{~m}$ $\left(0.25 \mathrm{~m}^{2}\right)$ square sample at 18 and 30 DAT. Weeds were collected at ground level, counted, separated by species and placed in forced air circulation, at $65^{\circ} \mathrm{C}$, until constant mass was achieved to determine the dry matter.

The maximum, minimum, daily thermal amplitude and soil temperature variation throughout the day were measured during the lettuce crop cycle. Soil temperature was measured from 0 to $18 \mathrm{DAT}$, because after this period, the leaf shading of the crop reduces the soil temperature variation.

Total water volume applied was determined based on the daily and weekly consumption of the crop.

Twelve lettuce plants, from the two central rows, were harvested at ground level at 30 DAT and weighed on a digital scale. The fresh matter mass of the aerial part from ground level to the plant extremity $\left(\mathrm{t} \mathrm{ha}^{-1}\right)$ and leaf number per plant from the basal leaves to the last open leaf, considering leaves larger than $5 \mathrm{~cm}$ were determined. The water use efficiency (USA, $\mathrm{kg} \mathrm{m}^{-3}$ ) was determined using the formula USA $=\mathrm{Y} / \mathrm{V}$, where $\mathrm{Y}$ is the yield $\left(\mathrm{tha}^{-1}\right)$ and $\mathrm{V}$ the total water volume applied $\left(\mathrm{m}^{3} \mathrm{ha}^{-1}\right)$ (Green et al., 2010).

The data were submitted to variance analysis and the means compared using Tukey's range test $(\alpha=0.05)$ using the statistical program R (R Development Core Team, 2014).

\section{RESULTS AND DISCUSSION}

Weed density and dry matter accumulation were $98 \%$ lower with the polyethylene film and recycled paper at 18 and 30 DAT in relation to uncovered and WW treatments (Table 1). The reduction of weed density and dry matter accumulation in lettuce crop with the soil covered with polyethylene film and recycled paper occurred due to physical barrier formation, preventing light passage, inhibiting weed germination by physical pressure on emergence and/ or weed growth (Moreno et al., 2013, Haapala et al., 2014). In agreement with obtained result in this study, a reduction of $80 \%$ of weed density with soil cover with paper has been reported for lettuce in Quebec, Canada (Brault \& Stewart, 2002), cucumber in Helsinki, Finland (Haapala et al., 2015), tomato in Zaragoza, Spain (Anzalone et al., 2010) and summer squash in Leingtanky, USA (Coolong, 2010). Recycled paper can be considered an efficient method to control weeds. The maximum soil temperature with the polyethylene film was $6.1^{\circ} \mathrm{C}$ higher until the $18 \mathrm{DAT}$ than in the treatment WR. The soil maximum temperature covered with 


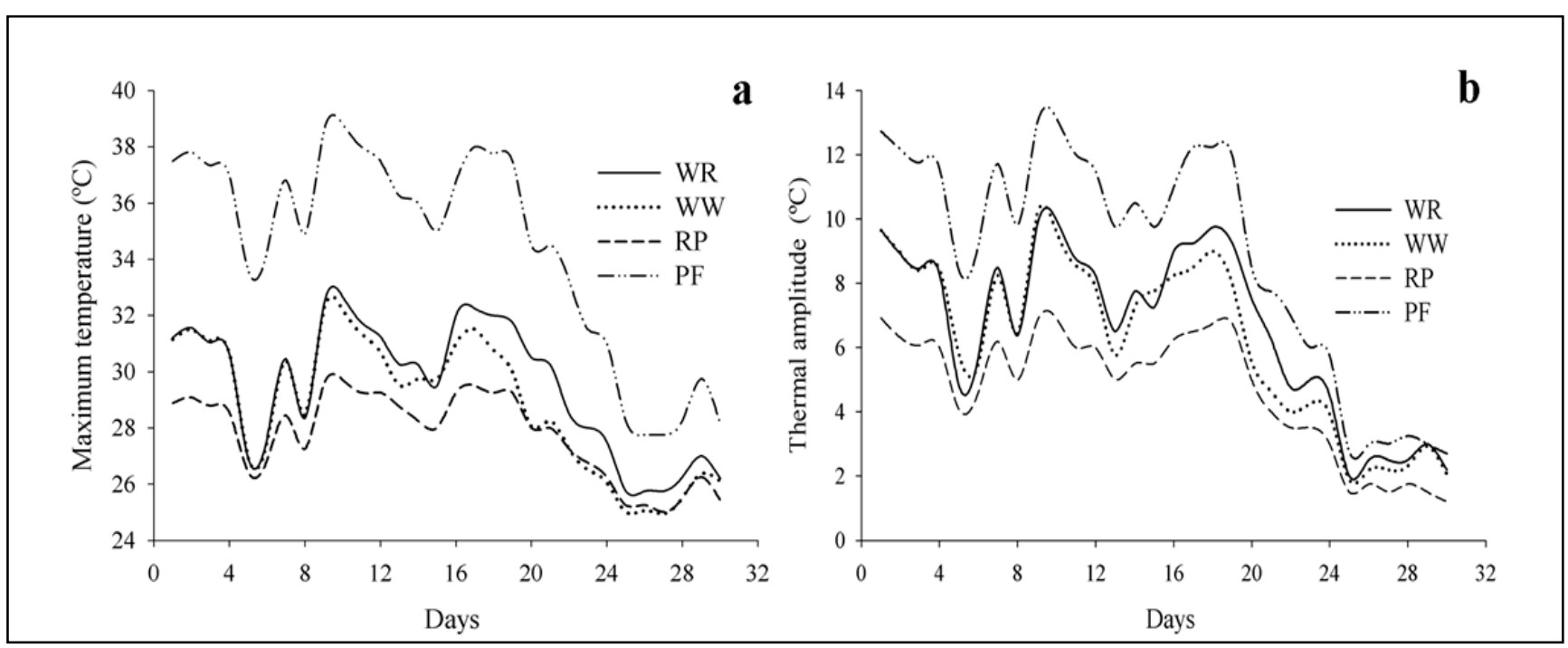

Figure 1. Maximum temperature (a) and thermal amplitude (b) of the soil during the lettuce cycle, in the treatments without soil cover with weed removal (WR), without soil cover and without weed removal (WW), covered with polyethylene film (PF) and recycled paper (RP). Viçosa, UFV, 2017.

recycled paper was 8.2 and $2.1^{\circ} \mathrm{C}$ lower than with polyethylene film and either WW, respectively (Figure 1a). The soil thermal amplitude with polyethylene film and recycled paper over time was 11.2 and $5.9^{\circ} \mathrm{C}$, respectively, up to 18 DAT (Figure 1b).

The reduction of soil temperature with recycled paper is due to the lower solar radiation absorption (Hapaala et al., 2014, 2015; Kader et al., 2017a), unlike the polyethylene film that absorbs more solar radiation, emits thermal radiation and increases soil temperature (Xiukang et al., 2015; Moreno et al., 2016; Gu et al., 2018). Lower thermal amplitude is attributed to the physical characteristics of the paper that reduces soil maximum temperature and increases minimum temperature (Moreno et al., 2008). The soil temperature reduction is due to lower energy absorption; so, the recycled paper shows the efficiency of this material to reduce the soil temperature.

The lettuce yield was higher in the soil covered with recycled paper (47.7 $\left.\mathrm{t} \mathrm{ha}^{-1}\right)$, followed by the treatments WR (41.7 $\left.\mathrm{t} \mathrm{ha}^{-1}\right)$ and polyethylene film $\left(37.2 \mathrm{t} \mathrm{ha}^{-1}\right)$. Production was lower in the treatment without cover and WW $\left(23.92 \mathrm{tha}^{-1}\right)$. The lettuce leaf number was highest in the treatments with recycled paper, polyethylene film and the treatment WR and lowest with WW. The lettuce plant height was higher with

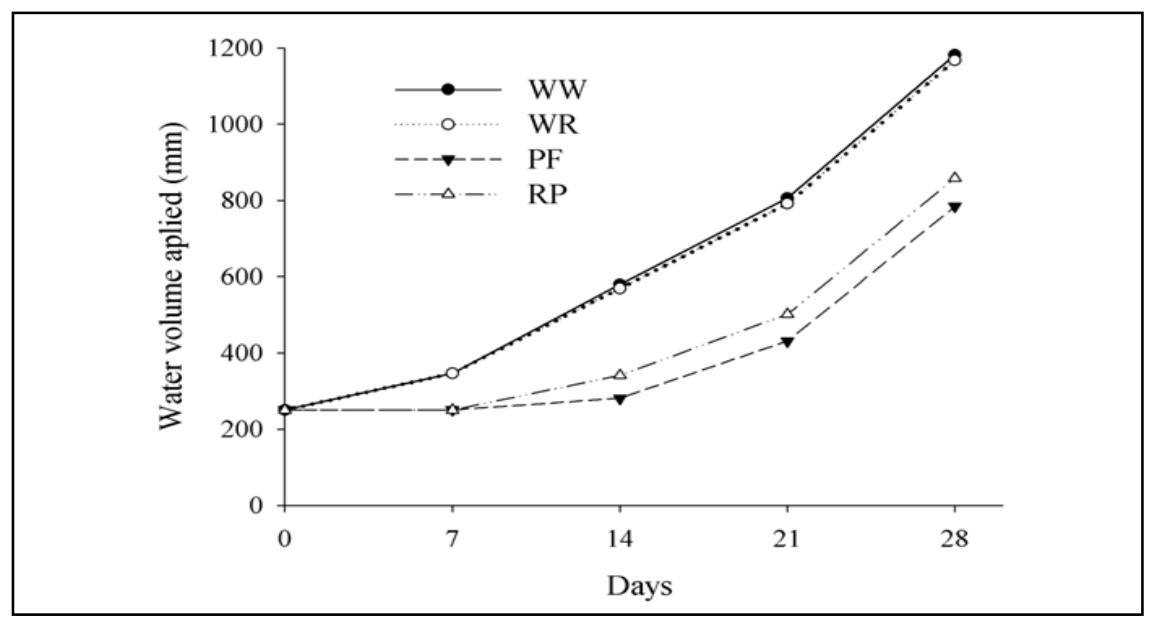

Figure 2. Water volume applied during the lettuce cycle, in the treatments soil without cover with weed removal (WR) and soil without cover and without weed removal (WW), covered with polyethylene film (PF) and recycled paper (RP). Viçosa, UFV, 2017.

the recycled paper and WW and similar in the other treatments (Table 2). The highest lettuce yield obtained in the soil covered with recycled paper is due to the soil temperature reduction, which is important because high temperature decreases growth and increases roots thickness, contributing to lower water and nutrient absorption (He et al., 2009). Additionally, higher soil temperature increases the root respiration rate (Klock et al., 1997) decreasing $\mathrm{CO}_{2}$ assimilation, stomatal conductance and relative leaf water content ( $\mathrm{He}$ et al., 2001). The lower plant yield observed in the uncovered treatment and WW was due to higher weed infestation competing with lettuce for water, light and nutrients, and decreasing leaf area and number of leaves (Ngouajio et al., 2003).

The total water volume applied was higher at 30 days in the treatments without cover WW and WR, 1,182 and $1,167 \mathrm{~m}^{3} \mathrm{ha}^{-1}$, respectively (Figure 2). This application was 33.4 and $26.5 \%$ lower with the polyethylene film and recycled paper mulching, respectively, than in the treatment without cover and WR. The water use efficiency was higher with recycled paper $(55.5 \mathrm{~kg}$ $\mathrm{m}^{-3}$ ), followed by polyethylene film 
Table 1. Density and dry matter of weeds (mean \pm standard error) in lettuce cultivation at 18 and 30 days after transplanting, in treatments without soil cover with weed removal (WR), without soil cover and without weed removal (WW), covered with polyethylene film (PF) and recycled paper (RP). Viçosa, UFV, 2017.

\begin{tabular}{lccccc}
\hline \multirow{2}{*}{ Treataments } & \multicolumn{2}{c}{ Density $\left(\right.$ plants $\left.\mathbf{~ m}^{-2}\right)$} & & \multicolumn{2}{c}{ Dry matter of weeds $\left(\mathbf{g ~ ~}^{-2}\right)$} \\
\cline { 2 - 3 } \cline { 6 - 7 } & $\mathbf{1 8}$ days & $\mathbf{3 0}$ days & & $\mathbf{1 8}$ days & $\mathbf{3 0}$ days \\
\hline WW & $338.4 \pm 65.8$ a & $325.67 \pm 70.6 \mathrm{a}$ & & $103.9 \pm 20.2 \mathrm{a}$ & $205.0 \pm 41.5 \mathrm{a}$ \\
$\mathrm{WR}$ & - & $85.8 \pm 4.83 \mathrm{~b}$ & & - & $9.1 \pm 0.7 \mathrm{~b}$ \\
$\mathrm{PF}$ & $0.8 \pm 0.3 \mathrm{~b}$ & $1.9 \pm 0.6 \mathrm{c}$ & & $0.2 \pm 0.1 \mathrm{~b}$ & $2.9 \pm 0.9 \mathrm{c}$ \\
$\mathrm{RP}$ & $2.2 \pm 0.7 \mathrm{~b}$ & $2.9 \pm 0.3 \mathrm{c}$ & & $0.2 \pm 0.1 \mathrm{~b}$ & $0.9 \pm 0.5 \mathrm{c}$ \\
\hline $\mathrm{CV}(\%)$ & 22.15 & 11.00 & & 20.13 & 14.00 \\
\hline
\end{tabular}

*Means followed by the same letter per column do not differ by the Tukey test $(\mathrm{P} \leq 0.05)$. -data not evaluated due to weeding in the plots. $\mathrm{CV}=$ coefficient of variation.

Table 2. Yield, number of leaves per plant (Lea), plant height $(\mathrm{H})$ and water use efficiency (WUE) in the lettuce culture (mean \pm standard error) in treatments (Trat) without soil cover with weed removal (WR), without soil cover and without weed removal (WW), covered with polyethylene film (PF) and recycled paper (RP). Viçosa, UFV, 2017.

\begin{tabular}{lcccc}
\hline Trat & Yield (t ha $\left.^{-1}\right)$ & Lea $\left(\right.$ planta $\left.^{-1}\right)$ & H $\mathbf{~ ( c m ) ~}$ & WUE $\left.\mathbf{( k g ~ m}^{-3}\right)$ \\
\hline WW & $23.9 \pm 2.4 \mathrm{~d}$ & $13.1 \pm 0.2 \mathrm{~b}$ & $28.3 \pm 0.4 \mathrm{ab}$ & $23.0 \pm 2.0 \mathrm{~d}$ \\
WR & $41.6 \pm 0.9 \mathrm{~b}$ & $17.0 \pm 0.2 \mathrm{a}$ & $24.8 \pm 0.2 \mathrm{bc}$ & $35.7 \pm 0.9 \mathrm{c}$ \\
PF & $37.2 \pm 0.2 \mathrm{c}$ & $17.5 \pm 0.8 \mathrm{a}$ & $24.0 \pm 0.4 \mathrm{c}$ & $47.4 \pm 0.2 \mathrm{~b}$ \\
RP & $47.7 \pm 0.4 \mathrm{a}$ & $18.0 \pm 0.7 \mathrm{a}$ & $26.7 \pm 0.8 \mathrm{a}$ & $55.5 \pm 0.5 \mathrm{a}$ \\
\hline CV (\%) & 7.52 & 7.30 & 4.37 & 6.10 \\
\hline
\end{tabular}

* Means followed by the same letter per column did not differ by the Tukey test $(\mathrm{P} \leq 0.05)$ $\mathrm{CV}=$ coefficient of variation.

mulching (47.4 $\left.\mathrm{kg} \mathrm{m}^{-3}\right)$ and the other treatments. This efficiency was 56 and $33 \%$ higher using recycled paper and the polyethylene film mulching, respectively, than in the soil without cover and WR $\left(35.7 \mathrm{~kg} \mathrm{~m}^{-3}\right)$.

The higher water volume applied in the uncovered treatments was due to a higher water evaporation rate from the soil and the highest weed density (Kader et al., 2017b; Sharma \& Bhardwaj, 2017). The reduction in water volume applied on plants is due to the physical barrier imposed by polyethylene film and recycled paper that reduces the soil water losses by evaporation (Haapala $e t$ al., 2014; Zhao et al., 2014), and thus keeping the soil moisture for a longer period (Chakraborty et al., 2008). The lower water use with the polyethylene film can be attributed to maintaining soil moisture for longer time, due to its lower porosity, which decreases soil water loss (Haapala et al., 2014). The greater efficiency of water use with recycled paper compared to polyethylene film is due to the higher yield of lettuce obtained, related to the volume of applied water and in addition to the reduction in maximum temperature and thermal amplitude that contributed to this increase.

Soil cover with recycled paper controls weeds, reduces soil temperature and water consumption and increases the yield and water use efficiency in lettuce crop.

\section{ACKNOWLEDGMENTS}

To Conselho Nacional de Desenvolvimento Científico e Tecnológico (CNPQ) for Master's cholarship of the first author, to the Departamento de Agronomia and postgraduate program of Fitotecnia of Universidade Federal de Viçosa (UFV). To the Ponte Nova Papéis Company (Ponte Nova-MG) for collaborating on the project for the recycled paper donation.

\section{REFERENCES}

ANZALONE, A; CIRUJEDA, A; AIBAR, J; PARDO, G; ZARAGOZA, C. 2010. Effect of biodegradable mulch materials on weed control in processing tomatoes. Weed Technology 24: 369-377.

BARBOSA, GL; GADELHA, FDA; KUBLIK, N; PROCTOR,A; REICHELM,L; WEISSINGER, E; HALDEN, RU. 2015. Comparison of land, water, and energy requirements of lettuce grown using hydroponic vs. conventional agricultural methods. International Journal of Environmental Research and Public Health 12: 6879-689.

BRAULT, D; STEWART, KA. 2002. Optical properties of paper and polyethylene mulches used for weed control in lettuce. HortScience 37: 87-91.

CHAKRABORTY, D; NAGARAJAN, S; AGGARWAL, P; GUPTA, VK; TOMAR, RK; GARG, RN; SAHOO, RN; SARKAR, A; CHOPRA, UK; SUNDARA SARMA, KS; KALRA, N. 2008. Effect of mulching on soil and plant water status, and the growth and yield of wheat (Triticum aestivum L.) in a semi-arid environment. Agriculture Water 95: 1323-1334.

COOLONG, T. 2010. Performance of paper mulches using a mechanical plastic layer and water wheel transplanter for the production of summer squash. HortTechnology 20: 319-324.

GREEN, TR; YU, Q; MA, L; WANG, TD. 2010. Crop water use efficiency at multiple scales. Agriculture Water Management 97: 1099-1101.

GU, X; LI, Y; DU, Y. 2018. Film mulched continuous ridge furrow planting improves soil temperature, nutrient content and enzymatic activity in a winter oilseed rape field, Northwest China. Journal Arid Land 13: 362-374.

HAAPALA, T; PALONEN, P; KORPELA, A; AHOKAS J. 2014. Feasibility of paper mulches in crop production. Agricultural and Food Science 23: 60-79.

HAAPALA, T; PALONEN, P; TAMMINEN, A, AHOKAS, J. 2015. Effects of different paper mulches on soil temperature and yield of cucumber (Cucumis sativus L.) in the temperate zone. Agricultural and Food Science 24: $52-58$.

HE, J; LEE, SK; DODD, IC. 2001. Limitations to photosynthesis of lettuce grown under tropical conditions: alleviation by root-zone cooling. Journal of Experimental Botany 52: 1323-1330.

HE, J; TAN, LP; LEE, SK. 2009. Root zone temperature effects on photosybthesis, 14C-photoassimilate partitioning and growth of temperate lettuce (Lactuca sativa cv. Panama) in the tropics. Photosynthetica 47: 95-103.

HUBBE, MA; GILL, RA. 2016. Fillers for papermaking: a review of their properties, usage practices, and their mechanistic role. BioResources 11: 2886-2963.

KADER, MA; SENGE, M; MOJID, MA. 2017b. Mulching type-induce soil moisture and 
temperature regimes and water use efficiency of soybean under rain-fed condition in central Japan. International Soil and Water Conservation Research 5: 302-308.

KADER, MA; SENGE, M; MOJID, MA; ITO, K. 2017a. Recent advances in mulching materials and methods for modifying soil environment. Soil \& Tillage Research 168: 155-166.

KLOCK, KA; TABER, HG; GRAVES, WR. 1997. Root respiration and phosphorus nutrition of tomato plants grown at a $36^{\circ} \mathrm{C}$ root zone temperature. Horticultural Science 122: 175-178.

KYRIKOU, I. 2007. Biodegradation of agricultural plastic films: A critical review. Journal of Polymers and the Environment 15: 125-150.

LAMONT, JW. 2005. Plastics: Modifying the microclimate for the production of vegetable crops. HortTechnology 15: 477-481.

LATI, RN; MOU, B; RACHUY, JS; SMITH, RF; DARA, SK; DAUGOVISH, O; FENNIMORE, SA. 2015. Weed management in transplanted lettuce with pendimethalin and s-metolachlor. Weed Technoly 29: 827-834.

MORENO, MM; CIRUJEDA, A; AIBAR, J. 2016. Soil thermal and productive responses of biodegradable mulch materials in a processing tomato (Lycopersicon esculentum Mill.) crop. Research 54: 207-215.

MORENO, MM; MORENO, A. 2008. Effect of different biodegradable and polyethylene mulches on productivity and soil thermal and biological properties in a tomato crop. Scientia Horticulturae 116: 256-263

MORENO, MM; MORENO, C; TARQUIS, AM. 2013. Mulch materials in processing tomato: a multivariate approach. Scientia Agricola 70: $250-256$

NGOUAJIO, M; MCGIFFEN, ME; HUTCHINSON, CM. 2003. Effect of cover crop and management system on weed populations in lettuce. Crop Protection 22: 57-64.

ODERO, DC; WRIGHT, AL. 2013. Phosphorus application influences the critical period of weed control in lettuce. Weed Science 61: 410-414.

R Development Core Team. 2014. R: A language and environment for statistical computing. Vienna, Austria: R Foundation for Statistical Computing.

RIBEIRO, AC; GUIMARÃES, PTG; ALVAREZ, VH. 1999. Recomendações para o uso de corretivos e fertilizantes em Minas Gerais, $5^{\text {th }}$ ed. Sociedade Brasileira de Ciência do Solo, Viçosa.

SCHIRMEL, J; ALBERT, J; KURTZ, MP; MUÑOZ K. 2018. Plasticulture changes soil invertebrate assemblages of strawberry fields and decreases diversity and soil microbial activity. Applied Soil Ecology 124: 379-393.

SHARMA, R; BHARDWAJ, S. 2017. Effect of mulch on soil and water conservation - A review. Agriculture Review 38: 311-315.

SILVA, KDP; DALLACORT, R; SANTI, A. 2017. Lettuce cultivation submitted to mulching treatments under open environment. Horticultura Brasileira 35: 415-418.

STEINMETZ, Z; WOLLMANN, C; SCHAEFER, M; BUCHMANN, C; DAVID, J; TRÖGER, J; SCHAUMANN, GE. 2016. Plastic mulching in agriculture. Trading short-term agronomic benefits for long-term soil degradation? Science of the Total Environment 550: 690705.

XIUKANG, W; ZHANBIN, L; YINGYING, X. 2015. Effects of mulching and nitrogen on soil temperature water content, nitrate- $\mathrm{N}$ content and maize yield in the Loess Plateau of China. Agricultural Water Management 161: 53-64.

ZHANG, S; LÖVDAHL, L; GRIP, H; TONG, Y; YANG, X; WANG, Q. 2009. Effects of mulching and catch cropping on soil temperature soil moisture and wheat yield on the loess plateau of China. Soil \& Tillage Research 102: 78-86.

ZHAO, H; WANG, RY; MA, BL; XIONG, YC; QIANG, SC; WANG, CL. 2014. Ridge-furrow with full plastic film mulching improves water use efficiency and tuber yields of potato in a semiarid rainfed ecosystem. Field Crops Research 161: 137-148. 